\title{
Clinical evaluation of periodontal pathogen levels by real-time polymerase chain reaction in peri-implantitis patients
}

\author{
Taichi Ito*, Gentaro Mori, Yukari Oda, Tomoki Hirano, Hodaka Sasaki, Shinya Honma, Yoshitaka Furuya and \\ Yasutomo Yajima
}

\begin{abstract}
Objective: The mechanisms underlying the onset and progression of peri-implantitis are similar to those of periodontitis, and the causative bacteria are believed to similar. Previous studies support an association between periimplantitis and periodontal pathogen. Thus, we investigated the bacterial flora of peri-implantitis patients in comparison to those of healthy implant and periodontitis patients.

Materials and methods: In total, 70 patients visiting Tokyo Dental College Chiba Hospital were divided into four groups: healthy, periodontitis, healthy implant, and peri-implantitis. For each group, the following five periodontal pathogens were detected using real-time polymerase chain reaction: Porphyromonas gingivalis, Aggregatibacter actinomycetemcomitans, Tannerella forsythia, Treponema denticola, and Prevotella intermedia.
\end{abstract}

Results: The average copy number of total bacteria was significantly higher in the periodontitis group than in the other groups. P. gingivalis was detected in the periodontitis and peri-implantitis groups at levels as high as 18.92\% and $12.29 \%$, respectively, and P. intermedia was found in the peri-implantitis group at a rate of $2.06 \%$. Nevertheless, periodontal pathogens were generally detected at lower levels in the peri-implantitis group than in the periodontitis group.

Conclusion: We found lower bacterial counts in the peri-implantitis group relative to the periodontitis group. Our results suggest that the peri-implant tissue is less resistant to bacteria, so even a small number of bacteria can be a risk factor for peri-implantitis and the causative agent of peri-implantitis can be bacteria other than periodontal pathogen.

Keywords: Clinical research, Diagnosis, Microbiology, Peri-implantitis

\section{Introduction}

Peri-implantitis is an inflammatory disease that affects the gums and bone structure around an osseointegrated dental implant. Without treatment, it can lead to bone destruction and may interfere with the long-term stability of the implant. The incidence and prevalence of periimplantitis in dental implant patients has been reported to range from 1 to $56 \%$ [1]. Thus, peri-implantitis is a

\footnotetext{
*Correspondence: ito@tdc.ac.jp

Department of Oral and Maxillo-Facial Implantology, Tokyo Dental

College, 1-2-2 Masago, Mihama-ku, Chiba 261-8502, Japan
}

potential risk for any implant patient and it should, therefore, be a major focus of clinical dentistry research.

The mechanisms underlying the onset and progression of peri-implantitis are similar to those of periodontitis. Although many factors can contribute to implant failure, evidence suggests that bacterial infection of peri-implant tissue is a major cause. The causative bacteria are also thought to be similar to periodontitis [2,3]. Although peri-implantitis and periodontitis are typically caused by bacterial infections, microbiological tests that can be easily applied clinically are yet to be established. Thus, both diseases are often treated without identifying 
the causative bacteria. In recent years, various chairside microbial tests have been developed to detect periodontal disease, including enzyme assays, DNA probe methods, and polymerase chain reaction (PCR). None of these tests, however, is widely employed due to their lack of convenience and prohibitive costs [4-7]. However, it is now possible to quantify periodontal pathogens by real-time polymerase chain reaction (RT-PCR) methods, so clinical bacterial tests are being performed more frequently [8-11].

In the present study, we used RT-PCR to investigate the periodontal pathogen flora in patients with peri-implantitis and periodontitis, as well as healthy implant patients, with the aim of assessing the similarity of the periodontal pathogens in each disease.

\section{Materials and methods}

\section{Patients and clinical evaluation}

In total, 70 adult Japanese patients (26 male and 44 female; mean age $\pm S D=58 \pm 8$ years) requesting dental implant treatment and peri-implantitis treatment, who were visiting the Department of Maxillo-facial and Oral Implantology at Tokyo Dental College Chiba Hospital, were evaluated in this study. The health status and background of each patient was recorded, including their age, sex, and probing pocket depth. The patients were also categorized into one of four groups: the healthy, healthy implant, periodontitis, and peri-implantitis groups (Table 1). All probing was carried out with a Williams probe and recorded at six sites (mesiofacial, midfacial, distofacial, mesiolingual, midlingual, and distolingual) in each tooth and in implants. None of the patients had received periodontal treatment or antibiotics for at least 6 months prior to participating in this study. Informed consent was obtained from each patient, and the study was conducted with approval from the Ethics Review Board of Tokyo Dental College (Approval No. 182).

\section{Sampling}

Prior to the sampling described below, the patients had been instructed not to brush their teeth or eat for at least $1 \mathrm{~h}$. At least one deep probing pocket depth site was selected in each patient. Each sampling site was isolated with cotton rolls, and supra-gingival plaque and saliva were carefully removed with sterile cotton pellets before being allowed to air dry. One paper point was inserted into each selected pocket until firm resistance was felt, and the paper points were kept in place for $30 \mathrm{~s}$ (Fig. 1). Once removed, the sample was stored at $-20{ }^{\circ} \mathrm{C}$ until it was processed.

Table 1 Classification of experimental groups

\begin{tabular}{llll}
\hline Classification & Number (male/female) & Age (mean \pm SD) & $\begin{array}{l}\text { Probing Pocket Depth } \\
\text { (PPD) (mean } \pm \text { SD) (mm) }\end{array}$ \\
\hline Healthy (h) group & $10(4 / 6)$ & $56.2 \pm 3.3$ & $3.26 \pm 0.46$ \\
Periodontitis (p) group & $16(6 / 10)$ & $58.7 \pm 6.1$ & $7.09 \pm 1.38$ \\
Healthy implant (hi) group & $17(5 / 12)$ & $54.5 \pm 13.2$ & $3.06 \pm 0.62$ \\
Peri-implantitis (pi) group & $27(11 / 16)$ & $62.4 \pm 9.8$ & $6.89 \pm 1.62$ \\
\hline
\end{tabular}

Subjects were divided into four groups based on severity of periodontal disease. Indicate the total number of people, the gender split in each group, mean age
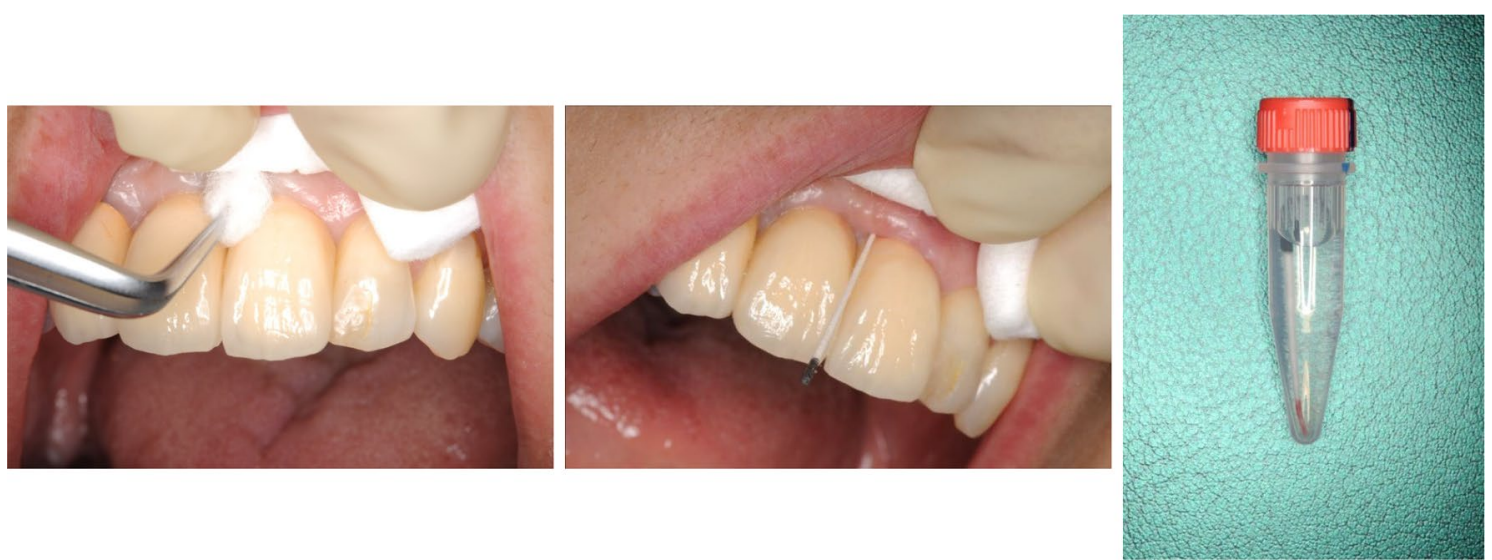

Fig. 1 Paper point method for sampling periodontal pathogens 


\section{RT-PCR}

In preparation for RT-PCR, $100 \mu$ l diluted samples were used for automated DNA extraction and purification with a Puregene Core Kit A (Qiagen, Tokyo, Japan). Subsequently, RT-PCR analysis was performed using the TaqMan ${ }^{\circledR}$ probe method (Miroku Medical Laboratory Inc., Nagano, Japan) and the following five periodontopathic bacteria were quantified: Aggregatibacter actinomycetemcomitans, Porphyromonas gingivalis, Tannerella forsythia, Treponema denticola, and Prevotella intermedia. The primer and probe sets for the five periodontal pathogens targeted, as well as the experimental conditions, are shown in Fig. 2 [12]. Following quantification, the bacterial copy-count numbers and proportion of each bacteria type to total copy-count were determined (with the latter being expressed as a percentage).

\section{Statistical analysis}

SPSS 15.0 for Windows (SPSS Inc., Chicago, IL, USA) was used to conduct statistical analysis. The percentages of each bacteria type to the total copy-count were compared using the Kruskal-Wallis test. $p$ values $<0.05$ were considered to be statistically significant.

\section{Results}

Figure 3 shows the average copy-count numbers of total bacteria in each group. The high values were observed in the periodontitis $\left(25 \times 10^{8}\right.$ copy-count $\left./ \mathrm{ml}\right)$ and periimplantitis $\left(3.5 \times 10^{8}\right.$ copy-count $\left./ \mathrm{ml}\right)$ groups; the copycount for the periodontitis group was significantly higher than that of any other group. No significant difference was detected in A. actinomycetemcomitans levels among the four groups (Fig. 4). However, the average percentage of $P$. gingivalis (relative to total copy-count) was markedly high in the periodontitis and peri-implantitis group (18.92\% and $12.29 \%$, respectively), and levels in the periodontitis group were significantly higher than in any other group $(p<0.01)$ (Fig. 5). The average percentages of T. forsythia $(p<0.01)$ and $T$. denticola $(p<0.01)$ were also significantly higher in the periodontitis group than in other groups (Figs. 6 and 7). In contrast, the average percentage of $P$. intermedia was markedly high in the peri-implantitis group at $2.07 \%$; indeed, it was significantly higher in the peri-implantitis group than in the healthy implant group $(p<0.05)$ (Fig. 8).

\section{Discussion}

A new finding in this study was that the total number of copies of bacteria comparing the four groups tended to be lower in the peri-implantitis group than in the

(1) DNA extraction

- DNA was extracted from paper point was inserted into selected pocket on each subject.

(2) TaqMan ${ }^{\circledR}$ probe method

\begin{tabular}{|c|c|c|}
\hline Periodontal pathogens & Primer/probe & Sequence $\left(5^{\prime}-3^{\prime}\right)$ \\
\hline Aggregatibacter actinomycetemcomitans & $\begin{array}{l}\text { Primer F } \\
\text { Primer R } \\
\text { Probe }\end{array}$ & $\begin{array}{l}\text { GAACCTTACCTACTCTTGAC } \\
\text { TGCAGCACCTGTCTCAAAGC } \\
\text { FAM-AGAACTCAGAGATGGGTTTGTGCCTTAGGG-TAMRA }\end{array}$ \\
\hline Tannerella forsythia & $\begin{array}{l}\text { Primer F } \\
\text { Primer R } \\
\text { Probe }\end{array}$ & $\begin{array}{l}\text { GGGTGAGTAACGCGTATGTAACCT } \\
\text { ACCCATCCGCAACCAATAAA } \\
\text { FAM-CCCGCAACAGAGGGATAACCCGG-TAMRA }\end{array}$ \\
\hline Prevotella intermedia & $\begin{array}{l}\text { Primer F } \\
\text { Primer R } \\
\text { Probe }\end{array}$ & $\begin{array}{l}\text { CGGTCTGTTAAGCGTGTTGT } \\
\text { CACCATGAATTCCGCATACG } \\
\text { FAM-TGGCGGACTTGAGTGCACGC-TAMRA } \\
\end{array}$ \\
\hline Treponema denticola & $\begin{array}{l}\text { Primer F } \\
\text { Primer R } \\
\text { Probe }\end{array}$ & $\begin{array}{l}\text { CCGAATGTGCTCATTTACATAAAGGT } \\
\text { GATACCCATCGTTGCCTTGGT } \\
\text { FAM-ATGGGCCCGCGTCCCATTAGC-TAMRA }\end{array}$ \\
\hline Porphyromonas gingivalis & $\begin{array}{l}\text { Primer F } \\
\text { Primer R } \\
\text { Probe }\end{array}$ & $\begin{array}{l}\text { GCGCTCAACGTTCAGCC } \\
\text { CACGAATTCCGCCTGC } \\
\text { FAM-CACTGAACTCAAGCCCGGCAGTTTCAA-TAMRA }\end{array}$ \\
\hline Universal & $\begin{array}{l}\text { Primer F } \\
\text { Primer R } \\
\text { Probe }\end{array}$ & $\begin{array}{l}\text { TCCTACGGGAGGCAGCAGT } \\
\text { GGACTACCAGGGTATCTAATCCTGTT } \\
\text { FAM-CGTATTACCGCGGCTGCTGGCAC-TAMRA }\end{array}$ \\
\hline
\end{tabular}

- $20 \mu \mathrm{l}$ of each periodontal pathogen reaction mix $+5 \mu$ of sample $+5 \mu$ of cDNA (or negative control)

- Thermal cycler conditions

$\left.50^{\circ} \mathrm{C}(2 \mathrm{~min}) \times 1,9^{\circ} \mathrm{C}(10 \mathrm{~min}) \times 1,95^{\circ} \mathrm{C}(15 \mathrm{~s}) \times 45,60^{\circ} \mathrm{C}(1 \mathrm{~min})\right) \times 45$

$\downarrow$

(3) Data analysis

Fig. 2 Taqman ${ }^{\circledR}$ real-time polymerase chain reaction assay was employed to determine the count of the targeted infectious agents using the primers and techniques indicated 


\section{Average copy-counts number $\left(10^{8} \mathrm{copy} / \mathrm{ml}\right)$ of total bacterium}

\section{Copy count $/ \mathrm{ml}$}

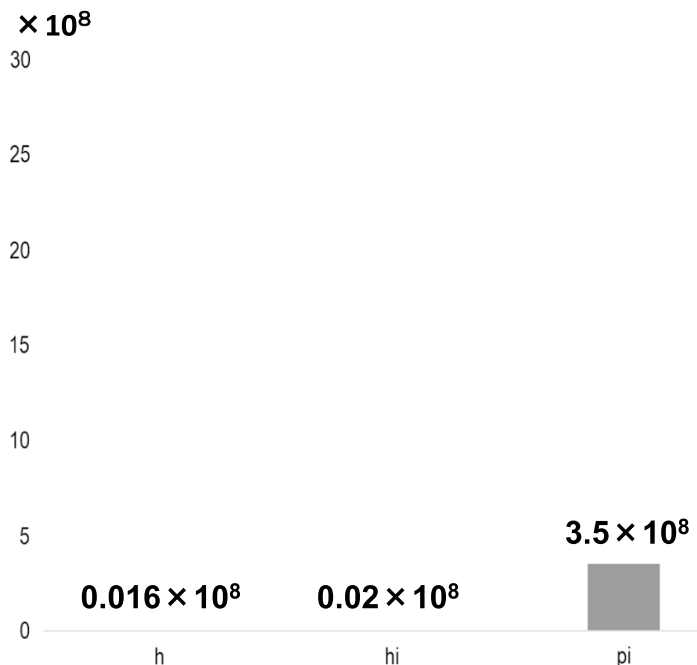

\section{$25 \times 10^{8}$}

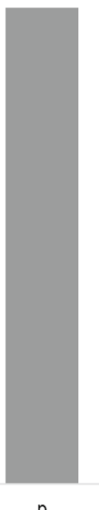

Tukey HSD ( $P$ value )

hi vs h : ns

hi vs pi: $*$

hi vs $p: *$

h vs pi : *

h vs $\mathrm{p}: *$

pi vs $\mathrm{p}: *$

\section{hi}

pi

Fig. 3 Average copy-count number $\left(10^{8}\right.$ copies/ml) of the four study groups [healthy (h) group, periodontitis (p) group, healthy implant (hi) group, and peri-implantitis (pi) group]

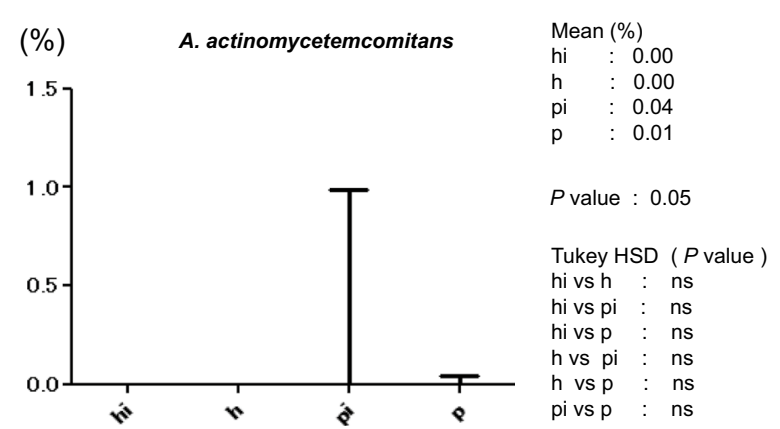

Fig. 4 Average proportion (\%) of bacteria to total copy-count for Aggregatibacter actinomycetemcomitans

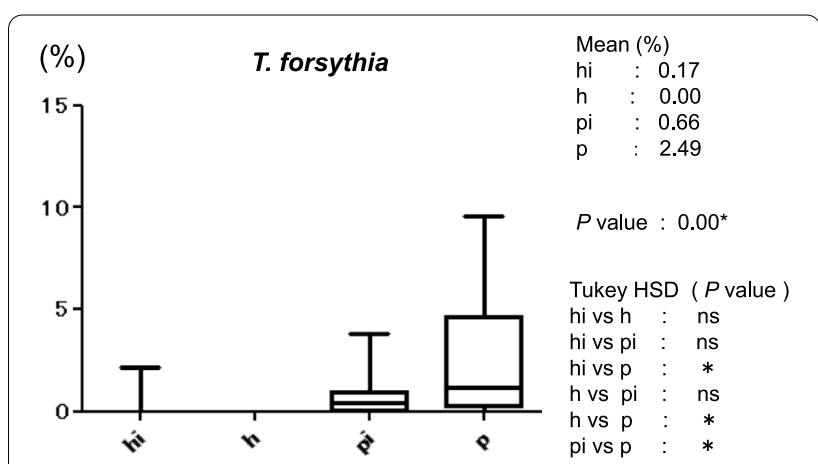

Fig. 6 Average proportion (\%) of bacteria to total copy-count for Tannerella forsythia

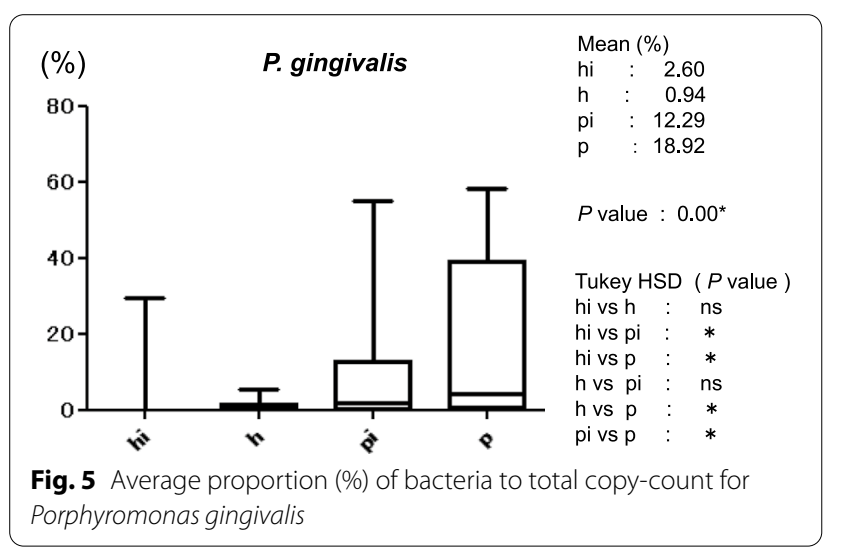

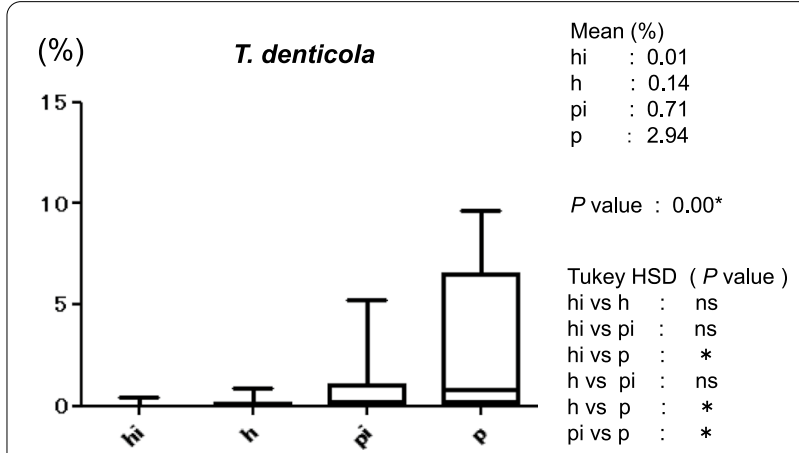

Fig. 7 Average proportion (\%) of bacteria to total copy-count for Treponema denticola 


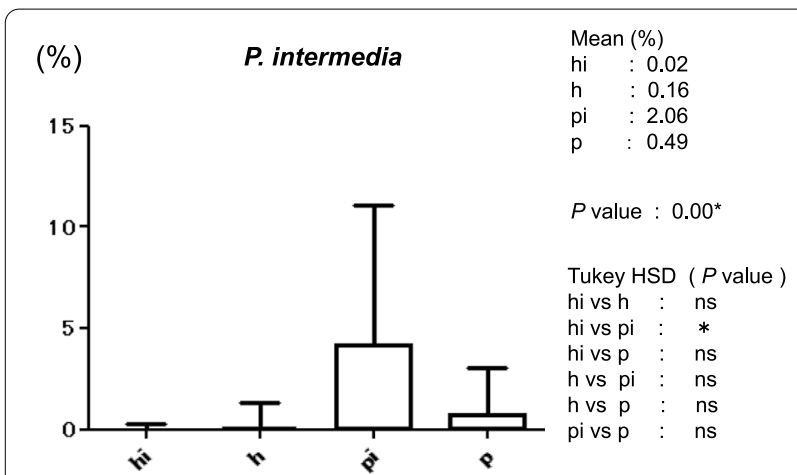

Fig. 8 Average proportion (\%) of bacteria to total copy-count for Prevotella intermedia

periodontitis group. However, the periodontal probing depth was the same in the periodontitis and peri-implantitis groups, suggesting that the peri-implant tissues have low resistance to bacteria even if the relative number of bacteria is small; thus, bacteria are clearly a risk factor for the development and progression of peri-implantitis. This finding is supported by reports that experimental periodontitis and peri-implantitis were caused by the formation of supragingival plaque in Beagle dogs [13, 14], and that inflammation of the tissue around the implant increased compared with tissue around natural teeth only 3 months after plaque formation. This suggests that the protective function of the tissue around the implant is inferior to that of the tissue around natural teeth. It has also been suggested that occlusal parafunction as a nonbacterial factor may be the cause of peri-implantitis [15]. However, it has been reported that occlusal parafunction does not affect changes in bone level in the peri-implant tissue $[16,17]$. At present, there seems to be no scientific evidence that occlusal parafunctions can be a factor in implant failure.

The results of this study showed that periodontal pathogens were detected more often in peri-implantitis patients than in patients with healthy implants, and that $P$. intermedia was present at significantly higher levels in the peri-implantitis group. This result is consistent with several previous studies of the periodontal pathogens associated with peri-implantitis; indeed, there is a bacteriological link between infection with periodontal pathogens and the failure of implant treatments [18]. In peri-implantitis, the bacterial infection occurs in the peri-implant tissue at the site of osseointegration; this complication can hinder the long-term stability of the implant $[19,20]$.

Periodontal disease patients are reported to be particularly susceptible to peri-implantitis. P. gingivalis, $T$. forsythia, and T. denticola, a group of bacteria known as the red complex, are considered to be highly likely to cause periodontal disease [21]. Similarly, these bacteria are linked to peri-implantitis. Maximo et al. reported a high proportion of red complex bacteria in subgingival plaques in peri-implantitis-affected areas [22]. Furthermore, peri-implantitis and periodontal disease-related bacteria have been reported to correlate with the bacteria associated with periodontitis [18]. In the present study, the five bacterial species, including the red complex, $A$. actinomycetemcomitans, and $P$. intermedia, were assessed as to whether they were associated with peri-implantitis and periodontitis. Only A. actinomycetemcomitans was rarely detected in patients with these diseases. This may be because $A$. actinomycetemcomitans is typically associated with aggressive periodontitis, which generally affects younger people, whereas the patients with implants in our study were relatively old (mean age $53.3 \pm 9.0$ years). The similarity in the bacteria detected in peri-implantitis and periodontitis is unsurprising, because peri-implantitis is thought to be caused by the periodontal pathogens transmitted from the periodontal pocket in the same oral cavity and by the same mechanism as periodontitis.

The detection of periodontal pathogen in the periimplantitis group was lower than that in the periodontitis group, it is possible that bacteria other than periodontal pathogens cause the onset and progression of periimplantitis. Previous studies have reported that various types of bacteria from chronic periodontitis are detected in affected areas of peri-implantitis [23]. Leonhardt et al. found that while periodontopathic bacteria were detected in about $60 \%$ of patients with peri-implantitis, Staphylococcus spp., enterobacteria, and Candida spp. were also detected in $55 \%$ of patients [24]. In studies that comprehensively analyzed the bacterial flora in the area affected by peri-implantitis, Parvimonas micra, Eubacterium spp., Peptococcus spp., and Butyrivibrio spp., among other bacteria, were also detected in addition to periodontopathic bacteria [25-27]. Thus, a variety of bacteria are active in peri-implantitis-affected areas; new methods, including next-generation sequencing, will be used in future to search for and identify these bacteria.

It is important that we understand the risk of periimplantitis and perform periodontal disease-related bacterial tests in patients with peri-implantitis to consider appropriate treatments for this disease. The RT-PCR method used in this study is a highly reliable test method that is rapidly becoming widespread in clinical practice as a test for COVID-19 [28, 29]. At present, the purpose of periodontal pathogen testing is to identify the causative agents of periodontal disease, to screen for high-risk patients with periodontal disease, to acquire information used to inform the patient and choose treatment, and to build toward a scientific consensus on the selection of 
antibacterial agents. Hereafter, further research aimed at identifying other bacterial species by new bacterial test methods such as the $16 \mathrm{~S}$ rRNA gene sequence will be needed. The results of the present study suggest that periodontal pathogen tests can be considered for use as effective pre-treatment risk tests and peri-implantitis tests during dental implant treatment.

\section{Conclusion}

The results of this study revealed that the number of bacteria in the peri-implantitis group was lower than that in the periodontitis group. The low resistance of periimplant tissue to bacteria suggests that even low bacterial counts may also be associated with peri-implantitis. In addition, the detection of periodontal pathogen in the peri-implantitis group was lower than that in the periodontitis group, suggesting that the causative bacteria of peri-implantitis may be bacteria other than periodontal pathogen.

\begin{abstract}
Abbreviations
RT-PCR: Real-time polymerase chain reaction; A. actinomycetemcomitans: Aggregatibacter actinomycetemcomitans; P. gingivalis: Porphyromonas gingivalis; T. forsythia: Tannerella forsythia; T. denticola: Treponema denticola; P. intermedia: Prevotella intermedia.
\end{abstract}

\section{Acknowledgements}

We would like to thank, ENAGO for assistance with the English of this manuscript.

\section{Authors' contributions}

$\mathrm{TI}, \mathrm{GM}, \mathrm{YO}, \mathrm{TH}, \mathrm{SY}, \mathrm{HS}, \mathrm{SH}, \mathrm{YH}$ and $\mathrm{YY}$ contributed to the data collection and evaluation. TI contributed to the statistical analysis, manuscript writing, and creation of figures. All authors read and approved the final manuscript.

\section{Funding}

This study was supported by Grant-in-Aid for Scientific Research, Young Scientists (B), 18791453, from the Japan Society for the Promotion of Science.

\section{Declarations}

\section{Ethics approval and consent to participate}

This research was conducted in accordance with the Helsinki Declaration of 1964 and subsequent ethical standards, with the approval of Tokyo Dental College Ethics Committee (World Medical 2013).

\section{Consent for publication}

All participants consented to publish their information details.

\section{Competing interests}

Taichi Ito, Gentaro Mori, Yukari Oda, Tomoki Hirano, Hodaka Sasaki, Shinya Honma, Yoshitaka Furuya and Yasutomo Yajima declare that they have no competing interests.

Received: 13 July 2020 Accepted: 30 September 2021

Published online: 06 October 2021

\section{References}

1. Fransson C, Wennström J, Tomasi C, Berglundh T. Extent of peri-implantitis-associated bone loss. J Clin Periodontol. 2009;36(4):357-63.
2. Socransky SS, Haffajee AD, Cugini MA, Smith C, Kent RL Jr. Microbial complexes in subgingival plaque. J Clin Periodontol. 1998;25(2):134-44.

3. Quirynen M, Vogels R, Peeters W, van Steenberghe D, Naert I, Haffajee A. Dynamics of initial subgingival colonization of 'pristine' peri-implant pocket. Clin Oral Implants Res. 2006;17(1):25-37.

4. Socransky SS, Haffajee AD. Evidence of bacterial etiology: a historical perspective. Periodontol 2000. 1994;5:7-25.

5. Takahashi J, Saito A, Nakagawa T, Yamada S, Ishihara K, Okuda K. Dynamics of serum Immunogloblin $\mathrm{G}$ advidity for Porphyromonas gingivalis in adult periodontitis. J Periodontol. 1998;69(3):367-73.

6. Komiya A, Kato T, Nakagawa T, Saito A, Takahashi J, Yamada S, Okuda K. A rapid DNA probe method for detection of Porphyromonas gingivalis and Actinobacillus actinomycetemcomitans. J Periodontol. 2000;71(5):760-7.

7. Ashimoto A, Chen C, Bakker I, Slots J. Polymerase chain reaction detection of 8 putative periodontal pathogens in subgingival plaque of gingivitis and advanced periodontitis lesions. Oral Microbiol Immunol. 1996;11(4):266-73.

8. Boutaga K, van Winkelhoff AJ, Vandenbroucke-Graus CM, Savelkoul $\mathrm{PH}$. Comparison of real-time PCR and culture for detection of Porphyromonas gingivalis in subgingival plaque sample. J Clin Microbiol. 2003;41(11):4950-4

9. Boutaga K, van Winkelhoff AJ, Vandenbroucke-Graus CM, Savelkoul PH. The additional value of real-time PCR in the quantitative detection of periodontal pathogens. J Clin Periodontol. 2006;33(6):427-33.

10. Kuboniwa M, Amano A, Kimura KR, Sekine S, Kato S, Yamamoto Y, Okahashi N, lida T, Shizukuishi S. Quantitative detection of periodontal pathogens using real-time polymerase chain reaction with TaqMan probes. Oral Microbiol Immunol. 2004;19(3):168-76.

11. Hyvarinen K, Laitinen S, Paju S, Hakala A, Suominen-Taipale L, Skurnik M, Kononen E, Pussinen PJ. Detection and quantification of five major periodontal pathogens by single copy gene-based real-time PCR. Innate Immun. 2009;15(4):195-204.

12. Ito T, Yasuda M, Kaneko H, Sasaki H, Kato T, Yajima Y. Clinical evaluation of salivary Periodontal pathogen levels by real-time polymerase chain reaction in patients before dental implant treatment. Clin Oral Implants Res. 2014;25(8):977-82.

13. Berglundh T, Lindhe J, Marinello C, Ericsson I, Liljenberg B. Soft tissue reaction to de novo plaque formation on implants and teeth. An experimental study in the dog. Clin Oral Implants Res. 1992;3(1):1-8.

14. Ericsson I, Berglundh T, Marinello C, Liljenberg B, Lindhe J. Long-standing plaque and gingivitis at implants and teetn in the dog. Clin Oral Implants Res. 1992:3(3):99-103.

15. Ekfeldt A, Christiansson U, Eriksson T, Lindén U, Lundqvist $S$, Rundcrantz $\mathrm{T}$, Johansson LÅ, Nilner K, Billström C. A retrospective analysis of factors associated with multiple implant failures in maxillae. Clin Oral Implants Res. 2001:12:462-7.

16. Bragger U, Aeschlimann S, Burgin W, Hämmerle CH, Lang NP. Biological and technical complications and failures with fixed partial dentures (FPD) on implants and teeth after four to five ysars of function. Clin Oral Implants Res. 2001;12:26-34.

17. Engel E, Gomez-Roman G, Axmann-Krcmar D. Effect of occlusal wear on bone loss and Periotest value of dental implants. Int J Prosthodont. 2001;14(5):444-50.

18. Persson GR, Renvert S. Cluster of bacteria associated with peri-implantitis. Clin Implant Dent Relat Res. 2013;16(6):783-93.

19. Mombelli A, Lang NP. The diagnosis and treatment of peri-implantitis. Periodontol 2000. 1998:17:63-76.

20. Quirynen M, De Soete M, van Steenberghe D. Infectious risks for oral implants: a review of the literature. Clin Oral Implants Res. 2002;13(1):1-19.

21. Socransky SS, Haffajee AD. Dental biofilms: difficult therapeutic targets. Periodontol 2000. 2002;28:12-55.

22. Máximo MB, de Mendonca AC, Renata Santos V, Figueiredo LC, Feres M, Duarte PM. Short-term clinical and microbiological evaluations of periimplant diseases before and after mechanical anti-infective therapies. Clin Oral Implants Res. 2009;20(1):99-108.

23. Mombelli A, Décaillet F. The characteristics of biofilms in peri-implant disease. J Clin Periodontol. 2011;38:203-13.

24. Leonhardt A, Revert S, Dahlen G. Microbial findings at failing implants. Clin Oral Implants Res. 1999;10(5):339-45. 
25. Koyanagi T, Sakamoto M, Takeuchi Y, Maruyama N, Ohkuma M, Izumi Y Comprehensive microbiological findings in peri-implantitis and periodontitis. J Clin Periodontol. 2013;40(3):218-26.

26. Kumar PS, Mason MR, Brooker MR, O'Brien K. Pyrosequencing reveals unique microbial signatures associated with healthy and failing dental implants. J Clin Periodontol. 2012;39(5):425-33.

27. da Silva ES, Feres M, Figueiredo LC, Shibli JA, Ramiro FS, Faveri M. Microbiological diversity of peri-implantitis biofilm by Sanger sequencing. Clin Oral Implants Res. 2014;25(10):1192-9.
28. Dramé M, Tabue Teguo M, Proye E, Hequet F, Hentzien M, Kanagaratnam L, Godaert L. Should RT-PCR be considered a gold standard in the diagnosis of COVID-19? J Med Virol. 2020;92(11):2312-3.

29. Yüce M, Filiztekin E, Özkaya KG. COVID-19 diagnosis-a review of current methods. Biosens Bioelectron. 2021;172:112752. https://doi.org/10.1016/j. bios.2020.112752 (Epub 2020 Oct 24)

\section{Submit your manuscript to a SpringerOpen ${ }^{\circ}$ journal and benefit from:}

- Convenient online submission

- Rigorous peer review

- Open access: articles freely available online

- High visibility within the field

- Retaining the copyright to your article

Submit your next manuscript at springeropen.com 